\title{
Radar and optical hybrid images to improve geoenvironmental mapping in Rio Grande do Norte state, Brazil
}

\author{
B. R. De Barros Pereira, V. E. Amaro \& D. R. Valentim da Silva \\ PPGG - Programa de Pesquisa e Pós-Graduação em Geodinâmica e \\ Geofísica, Universidade Federal do Rio Grande do Norte, Brazil
}

\begin{abstract}
The northern littoral of the Rio Grande do Norte state is a region under a strong dynamic influence concerning high energy coastal processes. These processes are increased by antropic actions joining with natural processes that change the natural landscape constantly. This area has lots of natural resources and it is very important economically, therefore it has been a target of studies of the main changes in the environmental aspects. In this context the geoenvironmental mapping have been defined and are included according to their physical and biological characteristics of the area and the territorial units that are linked to them. The territorial units follow the geological, vegetation, land-use/land-cover parameters. The geomorphology was the main parameter to define the geoenvironmental units. The geoenvironmental units were mapped on 1:50.000 scale based on the remote sensing images interpretation, using the fusion of multi sensor images (radar and optical). The images used were Radarsat-1, Landsat 5 TM (both from September 2006) and the SRTM from February 2000. The purpose of this methodology was to attend new resources to mapping geoenvironmental and their territorial units; previously each data has individual characteristics (an optical image has a spectral response while radar image provides textural and topographic data). The SRTM image was applied to emphasize the altimetry and morphology of the area. The digital image processing tools to integrate these data involved the precise registration, geometric correction and fusion through RGB and HSI color. The hybrid images created by these procedures was integrated and interpreted with the DEM (Digital Elevation Model) to merge four parameters: texture, morphology, spectral information and elevation in a single data. Then interpretation of the
\end{abstract}


hybrid images allowed mapping and accurate description of the geoenvironmental units.

Keywords: remote sensing, hybrid images, coastal dynamic, geoenvironmental and digital image process.

\section{Introduction}

The observation of environmental changes through multi-temporal analysis of optical images became a very important methodology in the case of coastal zones. These areas suffer changes constantly in a short period of time caused by a strong natural dynamic due to their geographical position. In the work area during the last ten years this methodology was applied in a lot of works and obtained high success, showing its importance. It can be found in Grigio et al. [1], Amaro and Araújo [2], De Barros Pereira et al. [3], De Barros Pereira et al. [4] and Souto et al. [5] for example.

In this paper, further than the use of traditional optical images, fusion with radar images was made. The main propose of this technique has shown a new methodology of digital image process to map geoenvironmental units in the coastal zone. The product of the radar and optical image fusion shows in only one image the capacity to analyze many aspects as: texture, morphology, relief and altimetry, dragged out from radar data, and spectral information, extracted from optical image. It was applied the optical image LANDSAT 5 TM and the radar image Radarsat-1, both data from September 2006. To extract the altimetry data and create the DEM was used the STRM image (from February 2000).

The interpretation of the hybrid image and the DEM allowed the mapping of units of land use, vegetation, geology and geomorphology. Joining these four parameters it was possible to define the geoenvironmental units. All the other units are included in a geomorphology unit so it was possible to use the geomorphology as the main parameter to define a geoenvironmental unit.

\subsection{Work area}

The work area is located in the northern coast of Rio Grande do Norte state, including the cities of Macau and Porto do Mangue in northeast Brazil. It is approximately $1.100 \mathrm{~km}^{2}$. The region is characterized with a high economic potential which is inserted into the oil industry, salt and shrimp farms and tourism.

The main access is made by the BR 406 road, around $190 \mathrm{~km}$ from Natal, the capital of the state (Figure 1).

This area is located in the equatorial zone that is characterized by high temperatures, high evaporation rates and low rainfall which the seasons are totally irregular presenting a rain period (April to July) and a dry period (the rest of the year). According to Nimer [6], the clime is semi arid, with annual average temperature of $27^{\circ} \mathrm{C}, 600 \mathrm{~mm}$ of rainfall and $70 \%$ of relative humidity (e.g. EMPARN [7]). The Piranhas-Assu River is the main one on the area, crossing it in a N-S trend until the Atlantic Ocean. 


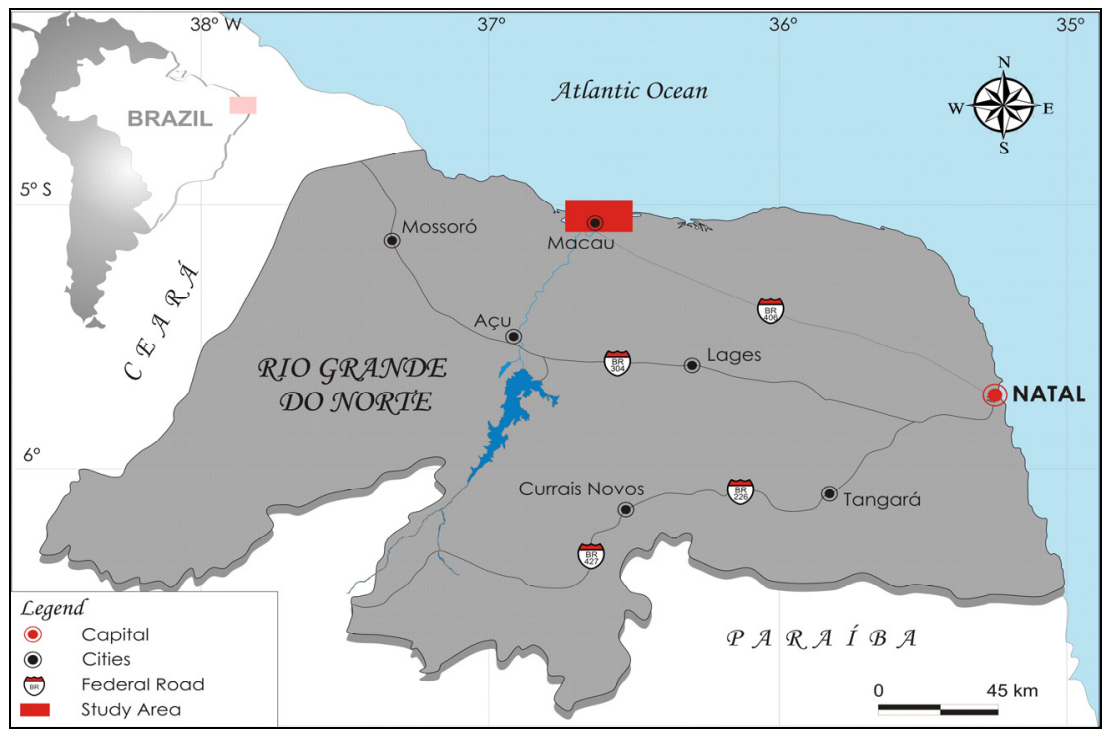

Figure 1: $\quad$ Located map of the study area.

The main coastal process agents that affect the area are: wind, marine currents, waves and tides. According to Caldas [8], there are two main wind trends: NE and ENE. The NE trend occurs among March and July and its velocity average is $4.8 \mathrm{~m} / \mathrm{s}$ while the ENE trend is frequent in the rest of year having velocity average of $7.7 \mathrm{~m} / \mathrm{s}$. The middle tidal is predominant which reaches $3.3 \mathrm{~m}$ in the highest level. The wave average height is $56 \mathrm{~cm}$.

\section{Methodology}

The methodology applied in this work had intention to extract the maximum information from each image individually using a sequence of process for each data. All the images passed for pre-processing, processing and then, was made the fusion of them creating the hybrid image with spectral, textural, morphology and relief characteristics.

The images used were: Landsat 5 TM, point/orbit 215/064, with seven spectral bands (six of them with $30 \mathrm{~m}$ of spatial resolution and one thermal band with $120 \mathrm{~m}$ ), captured on September $2^{\text {nd }}$, 2006; Radarsat-1 Mode standard has $12.5 \mathrm{~m}$ of spatial resolution and was obtained on September $26^{\text {th }}, 2006$; and SRTM from February 2000.

\subsection{Pre-processing}

Firstly, all the data were pre-processed. This step consists in the georeferencing of the images which was done in the Landsat and Radarsat-1 by the addiction of 55 points collected in situ with a geodesic GPS. It was used the UTM projection, 
Zone 24S and SAD-1969 Datum. In SRTM image the Datum was modified from WGS-1984 to SAD-1969.

\subsection{Processing}

The processing steps seek to extract the major differences in the surface units disposed in an image. Sought, do all these steps for each data separately respecting the single characteristics of each image. All of them were made in ArcGis 9.2 and Er-Mapper 7.1 software.

\subsubsection{Landsat image}

The processes applied in Landsat 5 TM were: RGB compositions (using different spectral bands or band ratio in each channel); image enhancement; and creation of Principal Components (PC).

It was used two methods to choose the bests RGB composition. 1) It is based in the statistical parameters as standard deviation and variance of spectral bands correlation. The analysis of this method provides the OIF (Optimum Index Factor) that represent the best combination of three spectral bands. As major the OIF value major will be the superficial differences among the units in the image (e.g. Cháves et al. [9]). The best combination involved the bands 1, 4 and 5, and it was chose RGB541 as better to this work; 2) It is based in the knowledge according to the spectral response. The best compositions were RGB753, RGB531, RGB432, RGB453, RGB345, RGB7/1-4/1-3/1, RGB7/3-5/3-4/3 and RGB7/4-5/3-4/2. After choosing the RGB compositions, all of them were enhanced to equalize the histogram, aiming to show a better contrast in the image. At last, the Principal Components were created. PC involves all the dimensional components in an image which each band represent one dimensional space. Through this technique is possible to extract a major amount of information from images (e.g. Medrano et al. [10]). The analysis of PC shows the major difference among superficial units in the composition R(PC1) G(PC2) $\mathrm{B}(\mathrm{PC} 3)$ from the 6 bands of Landsat image.

\subsubsection{Radarsat image}

The processes on Radarsat image consisted in the rescheduling of image, application of filters and enhancement. Firstly, the rescheduling was made due

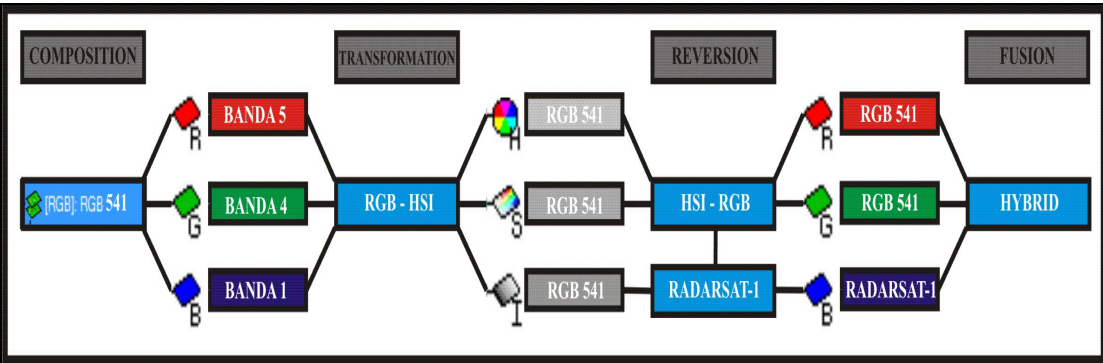

Figure 2: Flowchart showing the strategy of processing used in the fusion transformation RGB-HSI-RGBI. 
the original image had 16 bits. It was rescheduling to 8 bits to facilitate the processing of image on the software. Later, frost $3 \times 3$ filter was applied to remove the speckle noise. Following, the kernel N-S directional filter was applied together with the change of solar zenith angle to $70^{\circ} \mathrm{Az} / 30^{\circ}$. These applied tools improved the texture, topography and relief of superficial feature in the shadow direction and across it. Finally, the image was enhanced, SRTM IMAGE.

\subsubsection{SRTM image}

The SRTM passed by the change of Datum, previously WGS-1984 to SAD-1969 to join with the hybrid image. Posteriorly, shaded images were created through the change of solar zenith angle to $355^{\circ} \mathrm{Az} / 20^{\circ}$, extraction of topography contour lines and insertion of vertical exaggeration of 45 times to create the DEM.

\subsection{Fusion of data}

The fusion of optical and radar image consist in a combination of both data to create a hybrid image which can be analyzed in the aspects of texture, morphology, topographic and spectral (color). To combine the data was applied the transformation of color system RGB-HSI-RGBI (Figure 2). In this method, one composition of three bands is inserted RGB channels, then the bands passed by transformation to HSI system. The second step is to reverse the color system HSI to RGB and finally, the 'I' (intensity) channel, is added in the RGB system to integrate the radar image, forming the new system RGBI.

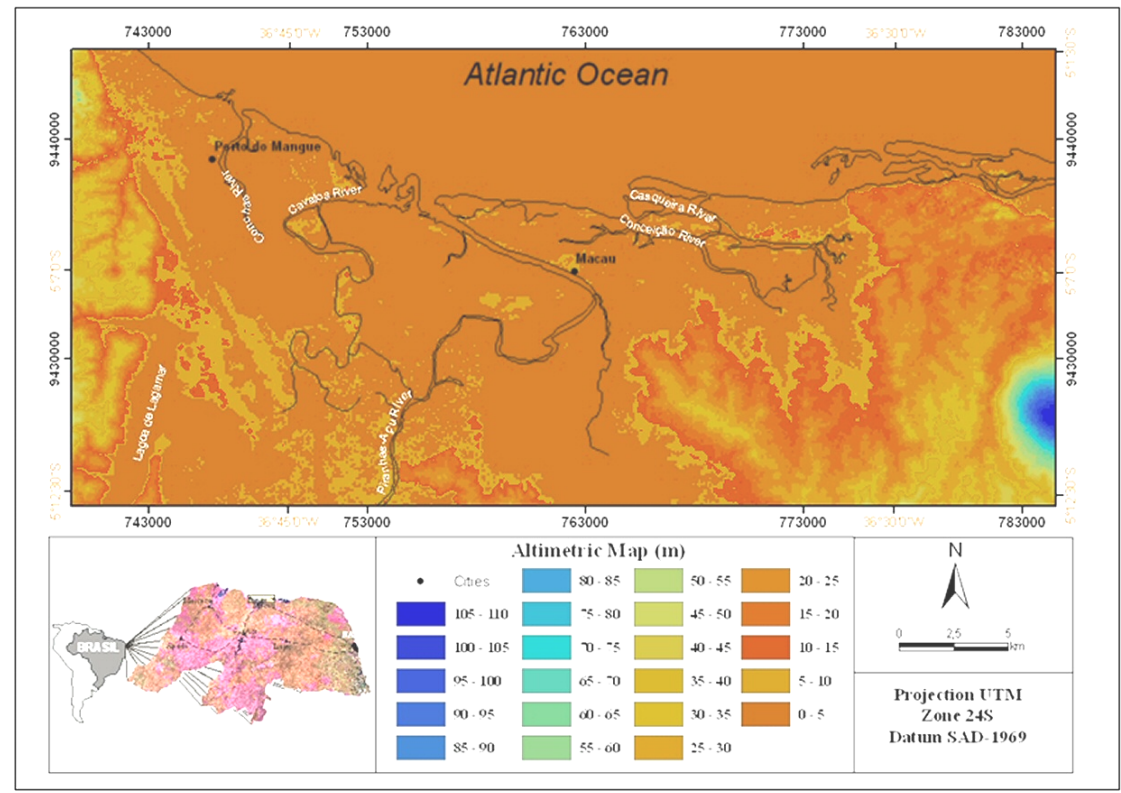

Figure 3: $\quad$ Altimetry map of the work area extracted from SRTM image. 
The DEM was created by the extraction of the altimetry from the SRTM (Figure 3). This data was integrated with the hybrid image and then it passed for many different view tests to see the best point of view to define all the topographic surfaces in the work area.

\section{Geoenvironmental units}

The characterization of geoenvironmental units became possible through analysis of the field aspects, hybrid image and DEM.

The field work analysis was made in situ which all the units referent to geology, vegetation, pedology and land use were mapped; the hybrid image analysis combined visual investigation and interpretation in the perception of the author. In the hybrid image the topographic and textural pattern were increased by the properties of color (hue, saturation and intensity) from the RGB-HSI transformation and also from the position of Radarsat-1 image into I (Intensity) channel. The DEM analysis consisted in the interpretation of textural, morphological color and altimetry parameters of superficial features. The altimetry in the work area varies from 0 to $110 \mathrm{~m}$ (Figure 3 ).

Four geoenvironmental units were mapped joining altimetry with all the superficial units which obey to geology, vegetation, pedology and land aspects showed in the hybrid images: planation surface, fluvial-estuarine/tidal flat, interdune flat and interdune depression (Figure 4).

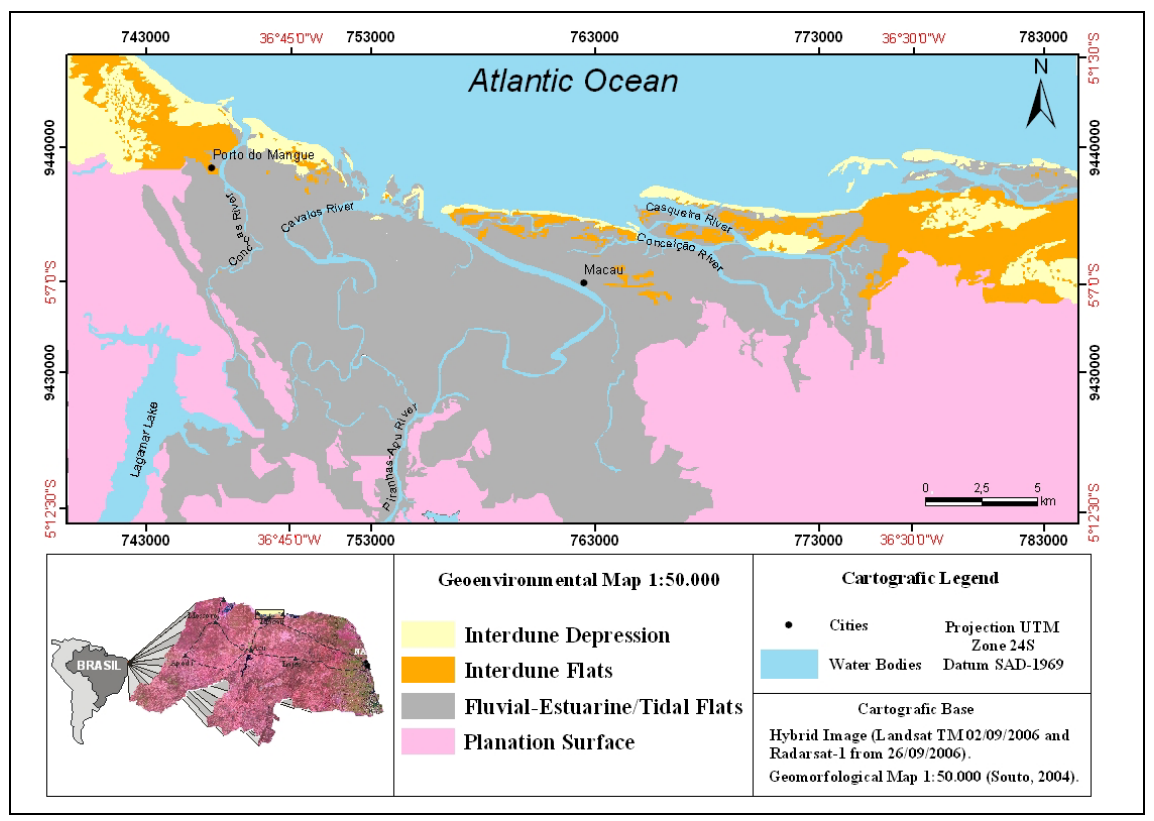

Figure 4: Geoenvironmental units map on the study area, at 1:50.000. 


\subsection{Planation surface}

This unit shows a flat morphology, sometimes a little wavy in some sectors and presents the highest elevation in the work area, reaching about $110 \mathrm{~m}$. The highest point is found in Mangue Seco Dome (Figures 5 and 6).

The planation surface was characterized by the geological units composed by calcarenites and calcilulites (Jandaíra Fm.); medium and fine grained sandstones and calcarenites (Tibau Fm.); volcanic rocks (Macau Fm.), conglomerates and coarse grained sandstones (Barreiras Fm.) and Quaternary alluvial deposits. Predominantly, this unit is cover by the caatinga vegetation and its soil is classified as soil association 1 (PLA) that is typical in caatinga's area. This soil is composed by quartz coarse grained sand, red and yellow coarse grained soil (e.g. Souto et al. [5]). On the NW portion of the study area the limit between the highs of planation surface and the low estuarine flats is marked by the morphological expression of a tectonic fault system, known as Afonso Bezerra fault system (Figure 5).

In the hybrid image were included in this unit: caatinga vegetation in RGBI541(RADARSAT-1), showing light green; the exposed soil and the cultivation area in red tones (Figure 6).

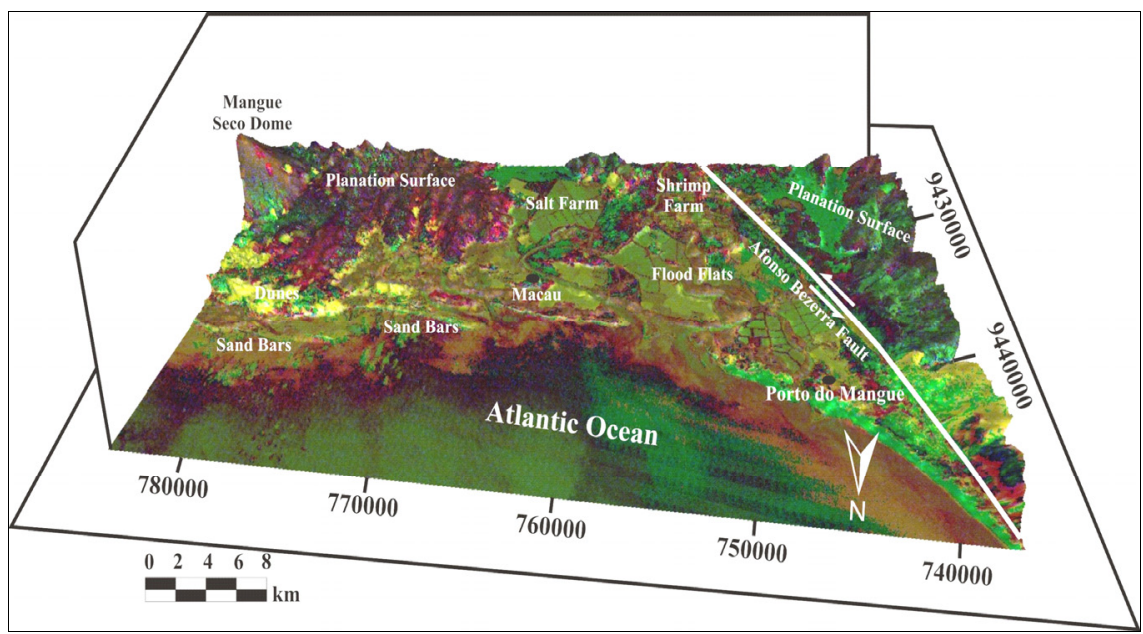

Figure 5: DEM combining the hybrid image $\mathrm{R}(\mathrm{PC} 1) \mathrm{G}(\mathrm{PC} 2) \mathrm{B}(\mathrm{PC}$ )I (RADARSAT-1) with SRTM. It shows the planation surface in purple tone; dunes fields in yellow tones; the flood area in yellow to light green tones; the Mangue Seco dome is the highest point while the flood flat is the lowest altimetry zone in the work area; and the Afonso Bezerra fault. (Colour in online version.) 


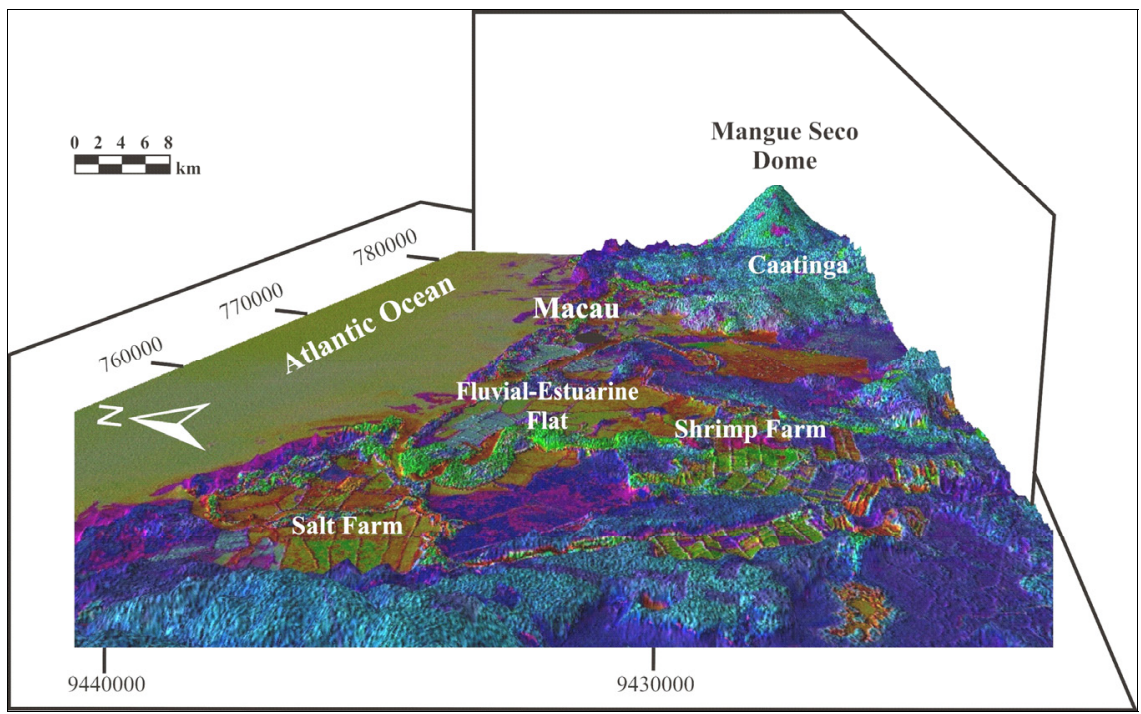

Figure 6: DEM combining the hybrid image RGBI541(RADARSAT-1) with SRTM. It shows the Caatinga in green tones; dunes fields in dark blue to purple tones; the square geometry of salt and shrimp farms. (Colour in online version.)

\subsection{Fluvial-estuarine/tidal flats}

This unit is located in the center of area, presenting the lowest altimetry values $(0$ to $5 \mathrm{~m})$. It is linked with tidal flats geological unit, having the flood and ebb tidal deposits.

In this area, the hydrodynamic processes have an important configuration in the changes of natural landscape. The main hydrodynamic agents are waves, tidal and fluvial channels that modified the coastal zone reworking it and creating erosion and depositional areas.

This unit presents a flat morphology with fine grained sediments as silt and mud, typically from flood areas. The soil is classified by Souto et al. [5] as Soil Association 2 that is characterized by mangrove mud soil. The mangrove vegetation is typical in this unit. In some local, the vegetation is substituted by salt and shrimp farms.

In the hybrid image, RGBI753(RADARSAT-1), the mangrove appears in light green tones, while in $\mathrm{R}(\mathrm{PC} 1 \mathrm{G}(\mathrm{PC} 2) \mathrm{B}(\mathrm{PC} 3) \mathrm{I}(\mathrm{RADARSAT}-1)$ the tones are dark purple; the flood area was emphasized in it hybrid image in green tones; this image also represent the shrimp farm in beige tone and the salt farm in light green tones (Figure 7). 


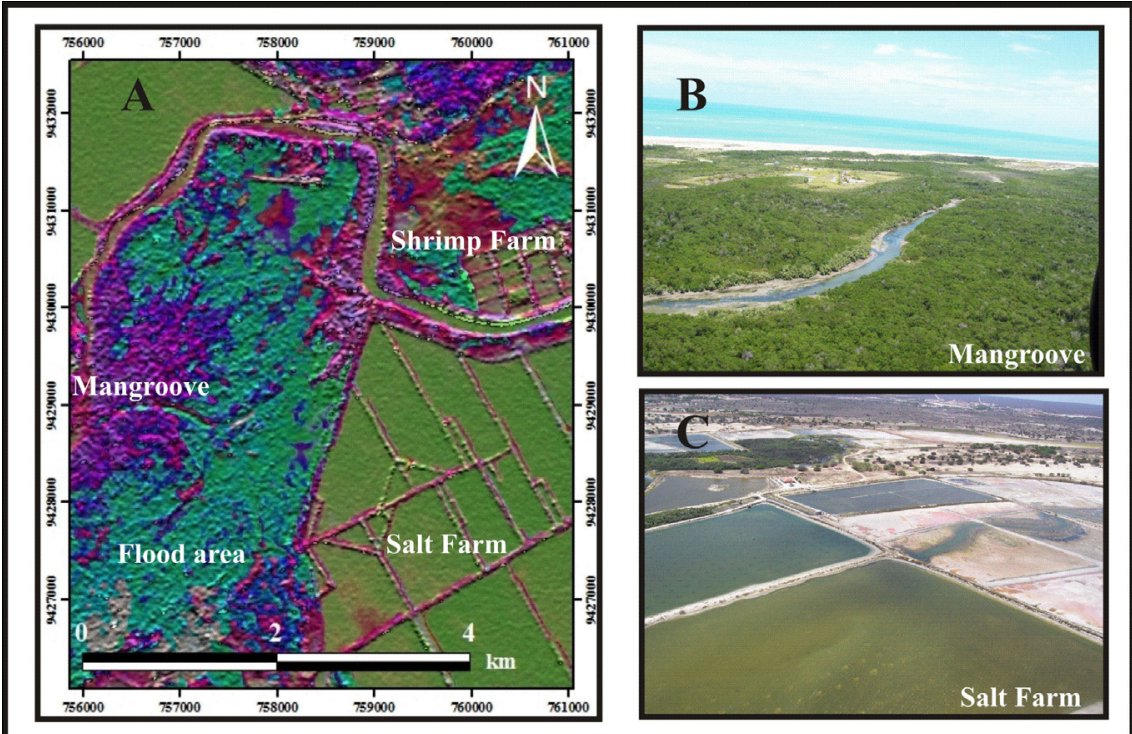

Figure 7: A Hybrid image R(PC1)G(PC2)B(PC3)I(RADARSAT-1) presenting salt farms in light green tone, flood area in dark green tone, mangrove in purple tone and shrimp farms in beige tone; B Mangrove; C Salt farms. (Colour in online version.)

\subsection{Interdune flat}

This unit is overlain by fixed dunes, situated around the deflation zone until the intertidal zone, with elevations until $20 \mathrm{~m}$. This unit is characterized by typical vegetation that protects the migration of dunes. This fixation following the standard called "sheet" dunes which they follow the Wind trend. (ENE and NE). The typical soil find in dunes is classified as (DQA) quartz sand, well selected, very round and frost brightness (e.g. Souto et al. [5]).

In the hybrid image, RGB753(RADARSAT-1), the fixed dunes were mapped in dark green tone (Figure 8).

\subsubsection{Interdune depression}

This unit is located in the beach zone and incorporates the field of non fixed dunes. It is characterized by well selected sand grains, composed by round quartz, very frost brightness, white to gray tones, deposited by the wind and waves action, showing the wavy pattern of morphology. In this region, the migration of dunes shows the "half moon standard" called barchan dunes. The altimetry of this unit reaches in the top of coastal zone around $10 \mathrm{~m}$ and $20 \mathrm{~m}$ in the far part of coastal line.

In the hybrid image, RGB753(RADARSAT-1), the field of dunes was characterized red and purple tones and its textural aspect (Figure 8). 


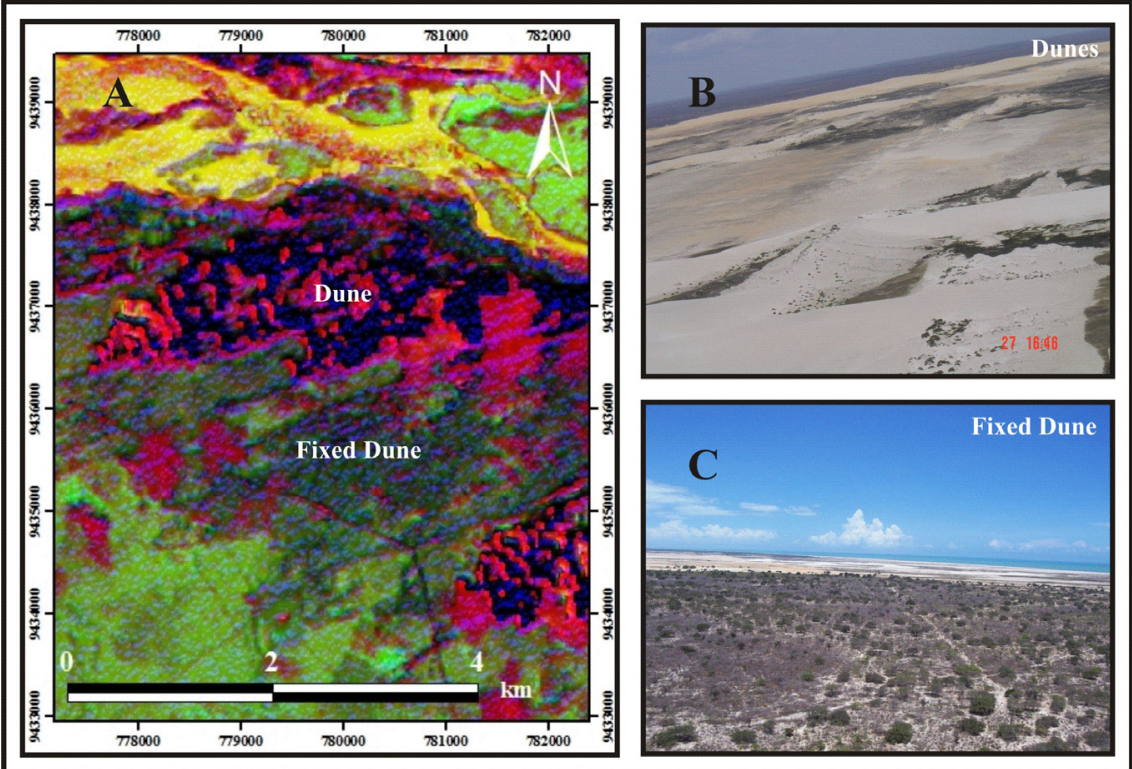

Figure 8: A Hybrid image RGBI753(RADARSAT-1) showing the dunes body in red and purple tones, and fixed dunes in dark green tone; B Field of dunes; C Typical vegetation fixing de body of dunes. (Colour in online version.)

\section{Conclusions}

The methodology to integrate multi-sensor images was satisfactory because all the objectives were fulfilled. The analysis of hybrid images gives a new data with textural, morphology, topographic and color (spectral) potential in only one data. Add to those parameters the altimetry is essential to determinate the geoenvironmental unit conclusions.

The bests hybrid images were: RGBI541(RADARSAT-1), RGBI753(RADARSAT-1) and R(PC1)G(PC2)B(PC3)I(RADARSAT-1). They gave a good response to define the superficial units, enhancing their differences with contrasting color tones and textural aspects.

The analysis of DEM shows the variation of altimetry in the work area from 0 to $110 \mathrm{~m}$ presenting as the highest point the Mangue Seco Dome.

The integrated analysis of field works, interpretation of hybrid images and DEM made possible to map four geoenvironmental units: planation surface (until $110 \mathrm{~m})$, fluvial-estuarine/tidal flat $(0-5 \mathrm{~m})$, interdune flat (until $20 \mathrm{~m}$ ) and interdune depression (until 20m). 


\section{Acknowledgements}

To the geoprocessing laboratory of UFRN (GEOPRO) and all people that work hard to make it a good work place. To my supervisor Prof. Dr. Venerando Eustáquio Amaro and Dalton Rosemberg Valentim da Silva. To Rede Cooperativa de Pesquisa em Monitoramento Ambiental de Áreas sob influência da Indústria Petrolífera, through PETRORISCO and HIDROSEMA projects.

\section{References}

[1] Grigio, A.M.; Amaro, V.E.; Diodato, M.A., Dinâmica espaço-temporal do uso e ocupação do solo no período de 1988-2004, do baixo curso do rio Piranhas-assu (RN): sugestões de acompanhamento integrado das atividades socioeconômicas impactantes em área costeira. Geografia (Rio Claro), v. 34, pp. 141-161, 2009.

[2] Amaro, V.E.; Araújo, A.B., Análise multitemporal da morfodinâmica da região costeira setentrional do Nordeste do Brasil entre os municípios de Grossos e Tibau, estado do Rio Grande do Norte. In: Revista de Gestão Costeira Integrada, v. 8(2), pp.77-100, 2008.

[3] De Barros Pereira, B. R.; Amaro, V. E.; Souza, A. S.; Aquino, A. G.; Valentim da Silva, D. R., Análise de dados orbitais multitemporais para avaliação de linha de costa nas áreas adjacentes ao município de Areia Branca/RN, com enfoque na região próxima ao estuário do Rio ApodíMossoró. In: Anais of XIII Remote Sensing Brazrazilian Simposium: Florianópolis, Brasil, pp. 2993-2998, 2007.

[4] De Barros Pereira, B. R.; Amaro, V. E.; Souza, A. S., Avaliação da Dinâmica Costeira da Foz do Rio Apodí-Mossoró e Áreas Adjacentes, Através de Produtos de Sensoriamento Remoto. Anais of $43^{\circ}$ Brazilian Geology Congress,: Aracajú/SE, Brazil, pp. 219, 2006.

[5] Souto, M.V.S., Castro, A.F., Grigio, A.M., Amaro, V.E. \& Vital, H., Multitemporal analysis of geoenvironmental elements of the coastal dynamics of the region of the Ponta do Tubarão, City of Macau/RN, on the basis of remote sensing products and integration in GIS. Journal of Coastal Research, v.39, pp. 1618-1621, 2006.

[6] Nimer, E., Climatologia da Região Nordeste do Brasil. Introdução à Climatologia Dinâmica. Revista Brasileira de Geografia, v. 34 (2), pp. 3-51, 1972.

[7] EMPARN, Empresa de Pesquisa Agropecuária do Rio Grande do Norte, http://www.emparn.rn.gov.br/links/meteorologia/meteorologia.asp

[8] Caldas, L. H. O., Late Quaternary coastal evolution of the northern Rio Grande do Norte coast, NE Brazil. PhD thesis, University of Kiel, Germany, pp.92, 2002.

[9] Cháves, P.S.J.; Berlin, G.L.; Bowel, J.A. Statistical method for selecting Landsat MSS Ratios. Journal of Applied Photogrammetry and Engineering, v. 8 (1), pp. 23-30, 1982. 
122 Coastal Processes II

[10] Medrano, M.C.N.; Corona, A.H.; Barajas, A.M., Caracterización litológica de regiones desérticas mediante técnicas de percepción remota: Un ejemplo en la franja costera central de Baja California, Mexico. Revista Mexicana de Ciências Geológicas, v. 22 (2), pp.229-245, 2005. 